\title{
PENGARUH SISTEM AKUNTANSI KEUANGAN DAERAH TERHADAP KUALITAS LAPORAN KEUANGAN PEMERINTAH KABUPATEN BANDUNG
}

\author{
Oleh : \\ R. Nelly Nur Apandi \\ (Dosen Prodi Akuntansi Fakultas Pendidikan Ekonomi \& Bisnis UPI) \\ Adrianus Fajar \\ (Alumni Prodi Akuntansi Fakultas Pendidikan Ekonomi \& Bisnis UPI)
}

\begin{abstract}
Abstrak
Dalam rangka menjalankan reformasi secara menyeluruh dan wewenang pengelolaan keuangan daerah, pemerintah harus menyusun sebuah sistem akuntansi pemerintahan yang mengacu pada SAP. Hal ini ditujukan agar pemerintah dapat menghasilkan laporan keuangan yang relevan, andal dan dapat dipercaya. Namun pada kenyataannya tetap ditemukan ketidakpatuhan terhadap peraturan perundang-undangan yang berlaku. Tujuan dari penelitian ini adalah untuk mengetahui besarnya pengaruh Sistem Akuntansi Keuangan Daerah terhadap Kualitas Laporan Keuangan Pemerintah Kabupaten Bandung. Metode penelitian yang digunakan adalah deskriptif dengan pendekatan survey analitik. Sampel dalam penelitian ini terdiri dari 24 organisasi perangkat daerah / SKPD di lingkungan Pemerintah Kabupaten Bandung melalui teknik purposive sampling. Analisis Statistik yang digunakan adalah regresi linier sederhana dengan uji t- statistik dengan tingkat signifikansi $5 \%$. Hasil dari penelitian ini menunjukkan bahwa penerapan Sistem Akuntansi Keuangan Daerah pada Pemerintah Kabupaten Bandung mendapat hasil sebesar $81,5 \%$ yang tergolong pada interval baik sedangkan kualitas laporan keuangan Pemerintah Kabupaten Bandung tergolong pada interval sangat baik dengan hasil 86,6\%. Sedangkan hasil pengujian dari penelitian ini menunjukan bahwa terdapat pengaruh antara Sistem Akuntansi Keuangan Daerah terhadap kualitas laporan keuangan Pemerintah Kabupaten Bandung melalui persamaan regresi $\mathrm{Y}=5,867+0,462 \mathrm{X}$ dengan koefisien determinasi sebesar 78,3\% yang berarti bahwa sebesar 78,3 \% perubahan mengenai kualitas laporan keuangan Pemerintah Kabupaten Bandung dapat diterangkan oleh variabel Sistem Akuntansi Keuangan Daerah sedangkan sisanya sebesar 21,7\% dipengaruhi oleh variabel lain.
\end{abstract}

Kata Kunci: Sistem Akuntansi Keuangan Daerah, Kualitas Laporan Keuangan

\section{Latar Belakang}

Laporan keuangan pemerintah daerah sebagai bentuk pertanggungjawaban pelaksanaan APBD harus disusun atau dihasilkan dari sebuah sistem akuntansi pemerintah daerah yang handal, yang bisa dikerjakan secara manual ataupun menggunakan aplikasi komputer. Namun mengingat sumber daya manusia yang masih sangat minim yang berspesialisasi di bidang akuntansi khususnya akuntansi keuangan sektor publik maka akan lebih tepat jika menggunakan sistem aplikasi komputer yang komprehensif dan sudah teruji. Hal ini akan dapat meminimalkan kesalahan proses akuntansi dan meningkatkan kualitas laporan keuangan yang dihasilkan.

Sebagai upaya konkrit untuk mewujudkan transparansi dan akuntabilitas pengelolaan keuangan negara / daerah adalah penyampaian laporan pertanggungjawaban keuangan pemerintah yang memenuhi prinsip tepat waktu dan disusun dengan mengikuti standar akuntansi pemerintahan yang telah diterima secara umum. Pernyataan tersebut diatur dalam UU No. 17 tahun 2003 tentang Keuangan Negara, PP No. 24 tahun 2005 tentang Standar Akuntansi Pemerintahan dan Permendagri No. 13 tahun 2006. 
Namun hal ini bertolak belakang dengan kenyataan yang ada. Seperti yang disampaikan oleh Daeng Nazier (Kepala Direktorat Utama Perencanaan Evaluasi Pengembangan dan Diklat BPK) yang dikutip dalam surat kabar Kompas edisi Rabu, 29 April 2009 bahwa LKPD tahun 2007 seharusnya diserahkan kepada BPK paling lambat bulan Maret 2008, akan tetapi sejumlah pemerintah kabupaten / kota terlambat menyerahkan laporan keuangan itu. Dari total 469 pemda, hanya 275 pemda yang menyerahkan LKPD tahun 2007 tepat waktu.

Pemerintah daerah selaku pengelola dana publik harus mampu menyediakan laporan keuangan yang diperlukan publik secara akurat, relevan, dan tepat waktu. Hal ini sejalan dengan teori agensi / teori keagenan yang diungkapkan Jensen dan Meckling (1976) dalam Sugiri (2003) bahwa hubungan keagenan sebagai sebuah kontrak yang menyatakan bahwa seorang atau lebih (prinsipal) meminta kepada orang lain (agen) untuk melakukan jasa tertentu demi kepentingan prinsipal, dengan mendelegasikan otoritas kepadanya.

Pada Laporan Keuangan Kabupaten Bandung dua tahun berturut-turut (2007-2008) selalu ditemukan ketidakpatuhan terhadap perundang-undangan yang berlaku, kecurangan, dan ketidakpatuhan yang material oleh BPK. Sedangkan dalam Standar Akuntansi Pemerintahan, laporan keuangan yang berkualitas salah satunya adalah harus disajikan secara andal. Andal disini berarti bebas dari pengertian menyesatkan dan kesalahan yang material, menyajikan secara jujur dan dapat diverifikasi.

\section{Rumusan Masalah}

1. Bagaimana Sistem Akuntansi Keuangan Daerah pada Pemerintah Kabupaten Bandung.

2. Bagaimana kualitas laporan keuangan pada Pemerintah Kabupaten Bandung.

3. Seberapa besar pengaruh Sistem Akuntansi Keuangan Daerah terhadap kualitas laporan keuangan Pemerintah Kabupaten Bandung.

\section{Kerangka Pemikiran}

Setelah hampir sepuluh tahun berlakunya otonomi daerah hampir belum ada kemajuan signifikan yang ditunjukan oleh pemerintah daerah. Laporan Keuangan Pemerintah Daerah (LKPD) dalam tiga tahun terakhir secara umum masih buruk (siaran pers, BPK RI, 23 Juni 2008).

Laporan keuangan pemerintah daerah sebagai bentuk pertanggungjawaban pelaksanaan APBD harus disusun atau dihasilkan dari sebuah sistem akuntansi pemerintah daerah yang handal, yang bisa dikerjakan secara manual ataupun menggunakan aplikasi komputer. Namun mengingat sumber daya manusia yang masih sangat minim yang berspesialisasi di bidang akuntansi khususnya akuntansi keuangan sektor publik maka akan lebih tepat jika menggunakan sistem aplikasi komputer yang komprehensif dan sudah teruii. Hal ini akan dapat meminimalkan kesalahan proses akuntansi dan meningkatkan kualitas laporan keuangan yang dihasilkan.

Pada hakekatnya di dalam pemerintahan daerah belum dapat menyusun laporan keuangan dan belum memahami sistem akuntansi. Sedangkan berdasarkan Peraturan Pemerintah No. 24 tahun 2005 tentang Standar Akuntansi Pemerintahan (SAP) menyatakan bahwa pemerintah menyusun sistem akuntansi pemerintahan yang mengacu pada SAP. Sistem akuntansi pemerintahan pada tingkat pemerintah pusat diatur dengan Peraturan Menteri Keuangan. Sistem akuntansi pemerintahan pada tingkat pemerintah daerah diatur dengan peraturan gubernur / bupati / walikota, mengacu pada Peraturan Daerah tentang pengelolaan keuangan daerah yang berpedoman pada Peraturan Pemerintah.

Mardiasmo (2004 : 35) mengatakan bahwa untuk dapat menghasilkan laporan keuangan yang relevan, handal dan dapat dipercaya, pemerintah daerah harus memiliki Jurnal Akuntansi Riset, Prodi Akuntansi UPI, Vol. 2, No. 1 
sistem akuntansi yang handal. Sistem akuntansi yang lemah menyebabkan laporan keuangan yang dihasilkan juga kurang handal dan kurang relevan untuk pembuatan keputusan. Saat ini sistem akuntansi yang dimiliki pemerintah daerah rata-rata masih lemah.

Permendagri No. 13 tahun 2006 tentang Pedoman Pengelolaan Keuangan Daerah Pasal 232 mengatakan bahwa sistem akuntansi pemerintahan daerah adalah : "serangkaian prosedur mulai dari proses pengumpulan data, pencatatan, pengikhtisaran, sampai dengan pelaporan keuangan dalam rangka pertanggungjawaban pelaksanaan APBD yang dapat dilakukan secara manual atau menggunakan aplikasi komputer."

Dalam rangka pertanggungjawaban pelaksanaan APBD, setiap SKPD menyusun dan melaporkan pertanggungjawaban pelaksanaan APBD tersebut secara periodik yang meliputi :

1. Laporan Realisasi Anggaran SKPD

2. Neraca SKPD

3. Catatan atas Laporan keuangan SKPD

Sistem akuntansi pemerintahan daerah dilaksanakan oleh Pejabat Pengelola Keuangan Daerah (PPKD), sedangkan sistem akuntansi Satuan Kerja Perangkat Dinas (SKPD) dilakukan oleh PPK-SKPD.

Berdasarkan Permendagri No. 13 tahun 2006 tentang Pedoman Pengelolaan Keuangan Daerah bahwa sistem akuntansi pemerintahan daerah sekurang-kurangnya meliputi sebagai berikut :

1. Prosedur Akuntansi Penerimaan Kas;

2. Prosedur Akuntansi Pengeluaran Kas;

3. Prosedur Akuntansi Aset Tetap / Barang Milik Daerah; dan

4. Prosedur Akuntansi Selain Kas.

Pemerintah, baik pusat maupun daerah harus bisa menjadi subyek pemberi informasi dalam rangka pemenuhan hak-hak publik, yaitu hak untuk mengetahui (right to know), hak untuk diberi informasi (right to be informed) dan hak untuk didengar aspirasinya (right to be heard and to be listened to). Hal ini semua pada akhirnya menuntut kemampuan aparatur pemerintah daerah dalam menghasilkan laporan keuangan yang berkualitas.

Karakteristik kualitatif laporan keuangan menurut PP No. 24 tahun 2005 tentang Standar Akuntansi Pemerintahan (SAP) adalah ukuran-ukuran normatif yang perlu diwujudkan dalam informasi akuntansi sehingga dapat memenuhi tujuannya. Keempat karakteristik berikut ini merupakan prasyarat normatif yang diperlukan agar laporan keuangan pemerintah daerah dapat memenuhi kualitas yang dikehendaki :

1. Relevan

2. Andal

3. Dapat Dibandingkan

4. Dapat Dipahami

Penelitian yang dilakukan oleh Erwin Danismaya (2009) dengan judul "Pengaruh Penerapan Sistem Akuntansi Keuangan terhadap Akuntabilitas Laporan Keuangan pada Pusat Pengembangan dan Pemberdayaan Pendidik dan Tenaga Kependidikan Bandung", menyatakan terdapat hubungan yang positif sebesar 52,8\% antara Sistem Akuntansi Keuangan terhadap Akuntabilitas Laporan Keuangan.

Dari pemaparan di atas berpijak pada teori-teori yang ada bahwa pemerintah daerah menyusun sistem akuntansi yang mengacu pada SAP guna menghasilkan laporan keuangan pemerintah daerah sesuai dengan SAP dan juga dengan adanya sistem akuntansi yang handal akan menghasilkan kualitas laporan keuangan. 


\section{Metode Penelitian}

Pada penelitian yang penulis lakukan ini, metode yang digunakan adalah metode deskriptif analitik, yaitu suatu metode yang menggambarkan keadaan yang sebenarnya berdasarkan data yang ada, kemudian data yang diperoleh selama penelitian diolah, dianalisis dan diproses lebih lanjut berdasarkan teori-teori yang telah dipelajari, dan dijadikan sebagai bahan pembahasan untuk menentukan hubungan, pengaruh, serta keterkaitan antara variabel-variabel yang diteliti. Dalam hal ini aktivitas yang dilakukan penulis adalah mempelajari pengaruh Sistem Akuntansi Keuangan Daerah terhadap kualitas laporan keuangan.

Menurut jenis data, penelitian ini menggunakan analisis data primer yang berasal dari hasil penyebaran kuesioner kepada responden.

Variabel-variabel yang terdapat dalam penelitian ini dapat didefinisikan sebagai berikut:

1. Sistem Akuntansi Keuangan Daerah pada penelitian ini dijadikan sebagai variabel independen (variabel X). Sistem Akuntansi Keuangan Daerah adalah serangkaian prosedur mulai dari proses pengumpulan data, pencatatan, pengikhtisaran, sampai dengan pelaporan keuangan dalam rangka pertanggungjawaban pelaksanaan APBD yang dapat dilakukan secara manual atau menggunakan aplikasi komputer. (Permendagri No. 13 tahun 2006).

2. Kualitas laporan keuangan pada penelitian ini dijadikan sebagai variabel dependen (variabel Y). Kualitas laporan keuangan adalah ukuran-ukuran normatif yang perlu diwujudkan dalam informasi akuntansi sehingga dapat memenuhi tujuannya (PP No. 24 tahun 2005).

Populasi dalam penelitian ini adalah seluruh Satuan Kerja Perangkat Dinas (SKPD) di Pemerintahan Kabupaten Bandung yang berjumlah 54 SKPD yang terdiri dari dinas, badan, kantor, dan kecamatan. Sampel pada penelitian ini adalah SKPD yang berbentuk dinas, badan dan kantor yaitu sebanyak 24 (dua puluh empat) SKPD. Adapun pertimbangan mengapa SKPD yang berbentuk kecamatan tidak dilibatkan dalam penelitian ini adalah karena pada SKPD yang berbentuk kecamatan sulit mendapatkan perizinan untuk penelitian ini mengingat adanya Pemilihan Kepala Daerah (PILKADA) Kabupaten Bandung yang akan segera berlangsung.

Sedangkan kuesioner sendiri terbagi menjadi 2 (dua) bagian yaitu kuesioner yang pertanyaannya berkaitan dengan variabel $\mathrm{x}$ dan kuesioner yang pertanyaannya berkaitan dengan variabel $y$. Kuesioner yang berisi pertanyaan variabel $\mathrm{x}$ akan disebarkan kepada fungsi akuntansi masing-masing dinas sedangkan kuesioner yang berisi pertanyaan variabel y akan disebarkan kepada kepala dinas dari masing-masing dinas, sehingga yang menjadi responden pada penelitian ini adalah fungsi akuntansi dan kepala dinas dari 24 SKPD yang menjadi sampel. Dalam penelitian ini, teknik pengumpulan data dilakukan dengan menggunakan data primer, yaitu data yang diperoleh secara langsung yang memiliki hubungan yang relevan dengan penelitian yang dilakukan. Data tersebut diperoleh dari hasil penyebaran kuesioner kepada responden.

Alat ukur yang digunakan untuk mengumpulkan data dalam penelitian ini adalah skala Likert dengan menggunakan variabel berukuran interval, karena kuesioner berupa pilihan berganda dengan lima alternatif jawaban yang bertujuan untuk mengukur sikap, pendapat maupun persepsi seseorang.

Dalam skala Likert, jawaban yang dikumpulkan dari pernyataan positif untuk setiap itemnya akan diberi bobot sebagai berikut : 
Tabel 1

Pemberian Skor Jawaban

\begin{tabular}{|c|c|}
\hline Pilihan Jawaban & Skor \\
\hline A & 5 \\
\hline B & 4 \\
\hline C & 3 \\
\hline D & 2 \\
\hline E & 1 \\
\hline
\end{tabular}

Menurut Sugiyono (2009) kriteria interpretasi skor berdasarkan jawaban responden dapat ditentukan sebagai berikut, "skor maksimum setiap kuesioner adalah 5 dan skor minimum adalah 1, atau berkisar antara 20\% sampai 100\%, maka jarak antara skor yang berdekatan adalah 16\%. ((100\%-20\%)/5)." Sehingga dapat diperoleh kriteria sebagai berikut :

Tabel 2

Interpretasi Skor

\begin{tabular}{|c|c|}
\hline Hasil & Kategori \\
\hline $20 \%-35,99 \%$ & Tidak Baik/Tidak Efektif \\
\hline $36 \%-51,99 \%$ & Kurang Baik / Kurang Efektif \\
\hline $52 \%-67,99 \%$ & Cukup Baik/Cukup Efektif \\
\hline $68 \%-83,99 \%$ & Baik/Efektif \\
\hline $84 \%-100 \%$ & Sangat Baik/ Sangat Efektif \\
\hline
\end{tabular}

Setelah data diperoleh dengan lengkap sesuai dengan yang dibutuhkan, selanjutnya dilakukan proses analisis data dan analisis data sebagai berikut:

1. Uji Validitas

Validitas Menurut Ghiselli (Dalam Jogiyanto H.M 2007: 120) Menunjukan seberapa jauh suatu tes atau satu set dari operasai-operasi mengukur apa yang seharusnya diukur.

Pengujian validitas tiap butir pernyataan kuesioner menggunakan validitas konstruksi, karena instrumen kuesioner yang digunakan adalah untuk mengukur sikap (nontest). Pengujian dilakukan dengan cara mengkorelasikan antara skor item setiap butir pernyataan dengan skor total, selanjutnya interpretasi dari koefisien korelasi yang dihasilkan, bila korelasi tiap faktor tersebut positif dan besarnya lebih dari atau sama dengan 0,3 maka dapat disimpulkan bahwa instrumen tersebut memiliki validitas konstruksi yang baik. (Sugiyono, $2008: 178$ )

$$
r=\frac{n \sum x y-\sum x \sum y}{\sqrt{\left\{n \sum x^{2}-\left(\sum x\right)^{2}\right\}\left\{n \sum y^{2}-\left(\sum y\right)^{2}\right\}}}
$$

Dimana $\quad x \quad$ : Skor tiap item pertanyaan

$y \quad$ : Skor total seluruh pertanyaan

2. Uji Reliabilitas

xy : Skor pertanyaan dikalikan dengan skor total.

Pengujian reliabilitas dalam penelitian ini menggunakan teknik belah dua (split half) yang dianalisis dengan rumus Spearman Brown. Untuk keperluan hal ini, maka butir-butir instrumen dibelah menjadi dua kelompok yaitu kelompok ganjil dan kelompok genap. Selanjutnya skor data tiap kelompok disusun sendiri, kemudian skor total antara kelompok ganjil dan kelompok genap dicari korelasinya. Setelah didapatkan korelasinya dilanjutkan dengan memasukannya ke dalam rumus sebagai berikut : 


$$
r_{i}=\frac{2 x r b}{1+r b}
$$

Dimana $r_{i} \quad$ : Reliabilitas internal seluruh instrumen

$r_{b} \quad$ : Korelasi pearson antara belahan pertama dan kedua.

Keputusan reliabilitas item dalam penelitian ini menggunakan kriteria Kaplan yang menyatakan: "it has been sugested that reliability estimates in the range of 0,7 to 0,8 are good enough for more purposes in basic research." (Robert M. Kaplan \& Denis P. Saccuzzo, Psychological Testing Principles, application and issues ; Brooks / Cole Publishing Company, Pacific Grove, California, 1993 p:126). Dari pernyataan di atas dapat diambil kesimpulan bahwa kelompok item dalam suatu dimensi dinyatakan reliabel jika koefisien reliabilitasnya tidak kurang dari 0,7 .

\section{Uji Normalitas Data}

Pengujian hipotesis dalam penelitian ini menggunakan statistik parametrik karena data yang akan diuji berbentuk interval. Karena akan menggunakan statistik parametrik, maka setiap data pada setiap variabel harus terlebih dulu diuji normalitasnya. Uji normalitas data dilakukan dengan uji Kolmogorov-Smirnov.

\section{Uji Linieralitas}

Uji linieritas digunakan untuk menguji linier tidaknya suatu data yang dianalisis yaitu variabel independen terhadap variabel dependen. Pada penelitian ini, uji linieritasnya dilakukan dengan uji $\mathrm{F}$.

\section{Menentukan Persamaan Regresi Linier Sederhana}

Persamaan regresi adalah persamaan matematik yang memungkinkan peramalan nilai suatu variabel dependen dari nilai variabel independen. Selain itu juga analisis regresi digunakan untuk memutuskan apakah naik dan menurunnya variabel dependen dapat dilakukan dengan menaikkan dan menurunkan variabel independen. Adapun bentuk persamaan regresi linier sederhana yang digunakan dalam penelitian ini adalah:

$$
Y=a+b X
$$

Keterangan :

$Y=$ Kualitas Laporan Keuangan

$\mathrm{a}=$ Konstanta

$b=$ Koefisien Regresi

$X=$ Sistem Akuntansi Keuangan Daerah

Menurut Riduwan (Dennis, 2009:52) harga a dan b dapat diketahui dengan menggunakan rumus sebagai berikut:

$$
\begin{gathered}
\mathrm{a}=\frac{\sum y \sum \text { 浬 }^{2}-\sum x \sum x y}{n \sum x^{2}-\left(\sum x\right)^{2}} \\
\mathrm{~b}=\frac{n \sum x y-\sum x \sum y}{n \sum x^{2}-\left(\sum x\right)^{2}}
\end{gathered}
$$

\section{Melakukan Pengujian Hipotesis (Uji t)}

Untuk menguji hipotesis secara parsial, dapat diuji dengan menggunakan rumus uji t sebagai berikut:

$$
t=\frac{b}{s_{b}}
$$

Keterangan:

b : koefisien regresi

$\mathrm{S}_{\mathrm{b}}:$ standart error dari variabel independen

Dalam pengujian hipotesis melalui uji $t$ ini, tingkat kesalahan yang digunakan peneliti adalah $5 \%$ atau 0,05 pada taraf signifikan $95 \%$. Pengujian t-statistik bertujuan untuk menguji signifikansi variabel independen dalam mempengaruhi variabel dependen. Pengujian t-statistik ini merupakan uji signifikansi dua arah. 
Hipotesis yang digunakan pada penelitian ini adalah sebagai berikut;

$\mathrm{H}_{0}: \beta=0$, Sistem Akuntansi Keuangan Daerah tidak berpengaruh terhadap kualitas laporan keuangan.

$\mathrm{H}_{1}: \beta \neq 0$, Sistem Akuntansi Keuangan Daerah berpengaruh terhadap kualitas laporan keuangan.

Pengujian dilakukan dengan cara membandingkan t-hitung yang didapat dari hasil regresi dengan t-tabel yang merupakan nilai kritis, dengan syarat-syarat:

a. Jika nilai t-hitung lebih besar atau sama dengan nilai t-tabel, maka hipotesis nol : ditolak, artinya bahwa Sistem Akuntansi Keuangan Daerah berpengaruh terhadap kualitas laporan keuangan, serta koefisien regresi variabel independen adalah signifikan terhadap variabel dependen.

b. Sebaliknya jika nilai t-hitung lebih kecil dari nilai t-tabel, maka hipotesis nol diterima, artinya bahwa Sistem Akuntansi Keuangan Daerah tidak berpengaruh terhadap kualitas laporan keuangan, serta koefisien regresi variabel independen adalah tidak signifikan terhadap variabel dependen.

Ketentuan:

$$
\left|\begin{array}{l}
\mathrm{t}_{\text {hitung }} \\
\mathrm{t}_{\text {hitung }}
\end{array}\right|<\mathrm{t}_{\text {a/2 }}\left(\mathrm{H}_{0} \text { diterima, } \mathrm{H}_{0} \text { ditolak, } \mathrm{H}_{1} \text { ditolak }\right)
$$

7. Menghitung Koefisien Determinasi

Koefisien determinasi $\left(\mathrm{R}^{2}\right)$ merupakan cara untuk mengukur ketepatan suatu garis regresi. Perhitungan koefisien determinasi juga digunakan untuk mengukur seberapa besar pengaruh variabel independen terhadap variabel dependen.

Untuk menghitung koefisien determinasi $\left(\mathrm{R}^{2}\right)$ digunakan rumus :

$$
R^{2}=\frac{n\left(a \cdot \sum Y+b_{1} \cdot \sum Y X_{1}+b_{2} \cdot \sum Y X_{2}\right)-\left(\sum Y\right)^{2}}{n \cdot \sum Y^{2}-\left(\sum Y\right)^{2}}
$$

(Suharyadi dan Purwanto, 2004:515)

berikut:

Nilai $R^{2}$ berkisar antara 0 dan $1\left(0<R^{2}<1\right)$, dengan ketentuan sebagai

a. Jika $\mathrm{R}^{2}$ semakin mendekati angka 1 , maka hubungan antara variabel bebas dengan variabel terikat semakin erat/dekat, atau dengan kata lain model tersebut dapat dinilai baik.

b. Jika $\mathrm{R}^{2}$ semakin menjauhi angka 1, maka hubungan antara variabel bebas dengan variabel terikat jauh atau tidak erat, atau dengan kata lain model tersebut dapat dinilai kurang baik.

\section{Hasil Penelitian}

\section{Sistem Akuntansi Keuangan Daerah}

Mengacu pada Peraturan Pemerintah No. 24 tahun 2005 tentang Standar Akuntansi Pemerintahan bahwa pemerintah menyusun sistem akuntansi yang mengacu pada Standar Akuntansi Pemerintahan. Sedangkan Standar Akuntansi Pemerintahan sendiri merupakan prinsip-prinsip akuntansi yang diterapkan dalam menyajikan laporan keuangan pemerintah, dengan demikian Standar Akuntansi Pemerintahan merupakan persyaratan yang mempunyai kekuatan hukum dalam upaya meningkatkan kualitas laporan keuangan pemerintah di Indonesia.

Dari data yang diperoleh dalam penelitian ini, dapat diketahui bahwa Pemerintah Kabupaten Bandung telah menerapkan atau melaksanakan Sistem Akuntansi Keuangan Daerah dengan baik. Hal ini terbukti dengan perhitungan yang disajikan sebelumnya bahwa dengan penilaian skala $0 \%-100 \%$, penerapan atau pelaksanaan Sistem Akuntansi Keuangan Daerah pada pemerintah Kabupaten Bandung telah mencapai 81,54\%. Hal ini 
dapat terjadi karena SKPD pada pemerintahan Kabupaten Bandung hampir seluruhnya sudah menerapkan Sistem Akuntansi Keuangan Daerah dan berpedoman pada Peraturan Pemerintah yang berlaku, terbukti dengan dijadikannya Permendagri No. 13 Tahun 2006 sebagai pedoman pelaksanaan Sistem Akuntansi Keuangan Daerah.

Namun bila dilihat lebih jauh, sebenarnya terdapat beberapa hal yang tidak sesuai dalam penerapan atau pelaksanaan Sistem Akuntansi Keuangan Daerah pada Pemerintah Kabupaten Bandung. Hal ini dapat terlihat dari jawaban - jawaban yang diberikan pada kuesioner variabel Sistem Akuntansi Keuangan Daerah. Seperti yang telah dibahas sebelumnya, kuesioner penelitian untuk variabel Sistem Akuntansi Keuangan Daerah pada awalnya berjumlah 17 item pertanyaan namun ada 4 item pertanyaan yang tidak valid sehingga hanya terdapat 13 item pertanyaan untuk variabel Sistem Akuntansi Keuangan Daerah. Berdasarkan hasil penelitian ke lapangan, ternyata 4 item yang tidak valid tersebut dikarenakan item pertanyaan tersebut tidak sesuai dengan kenyataan yang ada pada pemerintah Kabupaten Bandung.

Contoh nyata lainnya adalah pengelolaan Aset, berdasarkan Permendagri No. 13 tahun 2006 j.o permendagri No. 59 tahun 2007 bahwa pemerintah daerah melakukan penyusutan dengan menggunakan metode saldo menurun atau garis lurus sedangkan hasil jawaban yang diberikan ternyata masih banyak yang belum bahkan tidak melaksanakan penyusutan tersebut sama sekali. Hal ini mungkin terjadi karena kesulitan dalam menilai aset, akan tetapi hal ini juga sangat sering dialami oleh pemerintah daerah yang lainnya.

\section{Kualitas Laporan Keuangan}

Laporan keuangan disusun untuk menyediakan informasi yang relevan mengenai posisi keuangan dan seluruh transaksi yang dilakukan oleh suatu entitas pelaporan selama satu periode pelaporan. Laporan keuangan terutama digunakan untuk membandingkan realisasi pendapatan, belanja, transfer dan pembiayaan dengan anggaran yang telah ditetapkan, menilai kondisi keuangan, mengevaluasi efektivitas dan efisiensi suatu entitas pelaporan dan membantu menentukan ketaatannya terhadap peraturan perundang-undangan.

Dari data yang diperoleh dalam penelitian ini, tingginya persentase tingkat penerapan Sistem Akuntansi Keuangan Daerah yang diterapkan oleh Pemerintah Kabuipaten Bandung nyatanya telah mampu membuat kualitas laporan keuangan Pemerintah Kabupaten Bandung pun menjadi semakin bagus. Dengan data yang diperoleh dari penelitian ini bahwa kualitas laporan keuangan Pemerintah Kabupaten Bandung bila dinilai dalam skala $0 \%$ - 100\% yaitu sebesar $86,66 \%$.

\section{Pengaruh Sistem Akuntansi Keuangan Daerah terhadap Kualitas Laporan Keuangan pada Pemerintah Kabupaten Bandung}

Untuk mengetahui hubungan dan pengaruh antara Sistem Akuntansi Keuangan

Daerah dengan kualitas laporan keuangan pada Pemerintah Kabupaten Bandung, maka dilakukan perhitungan statistik dengan menggunanakan analisis regresi dan koefisien determinasi. Berdasarkan hasil analisis regresi, diperoleh nilai koefisien regresi $(b)$ sebesar 0,462 Dari nilai koefisien regresi tersebut, menunjukkan adanya hubungan positif antara Sistem Akuntansi Keuangan Daerah dengan kualitas laporan keuangan. Dari hasil perhitungan tersebut dapat disimpulkan bahwa pada Pemerintahan Kabupaten Bandung, ketika terjadi kenaikkan Sistem Akuntansi Keuangan Daerah sebesar 1 satuan, maka akan terjadi peningkatan kualitas laporan keuangan sebesar 0,462 satuan.

Setelah mengetahui adanya hubungan dan pengaruh antara Sistem Akuntansi Keuangan Daerah dengan kualitas laporan keuangan, maka untuk mengetahui seberapa besar pengaruh tersebut dapat dilihat dari besarnya nilai koefisien determinasi. Dari hasil perhitungan yang dilakukan, diperoleh nilai koefisien determinasi sebesar 78,3\%. Hal ini menunjukkan bahwa Sistem Akuntansi Keuangan Daerah memberikan kontribusi sebesar 
$78,3 \%$ dalam mempengaruhi kualitas laporan keuangan dan sisanya sebesar $21,7 \%$ dipengaruhi oleh faktor-faktor lain yang tidak diteliti dalam penelitian ini.

Laporan keuangan pemerintah daerah sebagai bentuk pertanggungjawaban pelaksanaan APBD harus disusun atau dihasilkan dari sebuah sistem akuntansi pemerintah daerah yang handal, yang bisa dikerjakan secara manual ataupun menggunakan aplikasi komputer. Mardiasmo (2004:35) pun mengatakan dalam bukunya "Otonomi Keuangan Daerah" bahwa untuk dapat menghasilkan laporan keuangan yang relevan, handal, dan dapat dipercaya, pemerintah daerah harus memiliki sistem akuntansi yang handal.

Hasil penelitian ini sesuai dengan teori tersebut, hal ini terjadi dikarenakan langkah-langkah yang seharusnya dijalankan oleh pemerintah daerah dalam menyajikan laporan keuangan dibuat dalam sebuah Peraturan Pemerintah yang artinya memiliki sifat memaksa sehingga hal tersebut harus dilaksanakan.

Namun berdasarkan penelitian di lapangan masih terdapat beberapa faktor yang dapat mempengaruhi kualitas laporan keuangan. Hal ini mungkin sudah mulai ramai menjadi bahan pembicaraan yaitu tentang pemberdayaan aparatur pegawai pemerintah daerah itu sendiri. Pemberdayaan aparatur pemerintah daerah ini berbicara lebih jauh tentang kompetensi dari para pegawai pemerintah daerah, karena ternyata pada pemerintah daerah sangat sedikit yang berspesialisasi di bidang akuntansi khususnya akuntansi sektor publik. Dengan kata lain, hal ini akan dapat meminimalkan kesalahan kesalahan pada proses akuntansi dan meningkatkan kualitas laporan keuangan yang dihasilkan. Meskipun demikian, penulis kira hal ini perlu diteliti lebih jauh lagi.

Hasil penelitian ini menunjukkan bahwa pelaksanaan Sistem Akuntansi Keuangan Daerah pada Pemerintah Kabupaten Bandung sudah baik, bahkan dengan pelaksanaan Sistem Akuntansi Keuangan Daerah tersebut dapat meningkatkan kualitas laporan keuangan yang dihasilkan oleh Pemerintah Kabupaten Bandung.

\section{Simpulan}

Berdasarkan hasil penelitian dan pembahasan yang telah dipaparkan pada bab sebelumnya, maka penulis dapat mengambil simpulan bahwa :

1. Sistem Akuntansi Keuangan Daerah pada Pemerintah Kabupaten Bandung telah dilaksanakan dengan baik. Dari hasil data yang diperoleh bahwa Sistem Akuntansi Keuangan Daerah termasuk pada kategori yang baik atau efektif. Hal ini terjadi karena Pemerintah Kabupaten Bandung telah menerapkan prosedur akuntansi sesuai dengan peraturan-peraturan yang berlaku yaitu dengan dijadikannya Permendagri No. 13 tahun 2006 sebagai pedoman dalam pengelolaan Keuangan Daerah.

2. Kualitas laporan keuangan pada Pemerintah Kabupaten Bandung telah disajikan atau dihasilkan dengan sangat baik. Dari hasil data yang diperoleh bahwa kualitas laporan keuangan termasuk pada kategori sangat baik. Hal ini mungkin terjadi karena tuntutan dari otonomi daerah yang sudah semakin mendesak pemerintah daerah dalam memperbaiki kinerja termasuk dalam penyajian laporan keuangan.

3. Sistem Akuntansi Keuangan Daerah memiliki pengaruh dengan arah positif terhadap kualitas laporan keuangan. Dari hasil tersebut dapat diartikan bahwa jika Sistem Akuntansi Keuangan Daerah semakin membaik maka akan menyebabkan semakin membaiknya juga kualitas laporan keuangan, dan juga berlaku sebaliknya.

\section{Saran}

Berdasarkan hasil penelitian yang telah dilakukan, penulis dapat mengajukan saran sebagai berikut :

1. Hendaknya Pemerintah Kabupaten Bandung perlu lebih mengadakan pelatihan tentang Sistem Akuntansi Keuangan Daerah kepada seluruh pegawainya untuk membentuk sebuah pemahaman yang lebih kepada para pegawai. Selain itu juga Pemerintah 
Kabupaten Bandung mulai lebih memikirkan tentang spesialisasi kepada para pegawai, sehingga bisa memaksimalkan tugas pokok dan fungsi masing-masing bagian terutama dalam menyusun laporan keuangan.

2. Bagi peneliti selanjutnya yang tertarik untuk melakukan penelitian sejenis, hendaknya menambah variabel penelitian dengan pemberdayaan ataupun kompetensi para pegawai Pemerintah Kabupaten Bandung terhadap kualitas laporan keuangan karena berdasarkan penelitian di lapangan hampir seluruh fungsi akuntansi Pemerintah Kabupaten Bandung tidak berasal dari latar belakang pendidikan yang sesuai.

\section{Daftar Pustaka}

Abdul Halim. (2007). Akuntansi Keuangan Daerah. Jakarta: Salemba Empat.

Abdul Halim. (2007). Pengelolaan Keungan Daerah. Yogyakarta : UPP STIM YKPN.

Erwin Danismaya. (2009). "Pengaruh Penerapan Sistem Akuntansi Keuangan terhadap Akuntabilitas Laporan Keuangan pada Pusat Pengembangan dan Pemberdayaan Pendidik dan Tenaga Kependidikan Bandung". Skripsi. Bandung : Fakultas Ekonomi Universitas Padjajaran.

Firmansyah Irman. (2008). "Peran Sistem Akuntansi Keuangan Daerah terhadap Transparansi dan Akuntabilitas Keuangan Daerah pada Provinsi Jawa Barat". Skripsi. Bandung : Fakultas Ekonomi Universitas Widyatama.

Iman Abdurachman. (2009). "Pengaruh Kompetensi Aparatur terhadap Kualitas Laporan Keuangan Organisasi Perangkat Daerah Pemerintah Kabupaten Purwakarta". Skripsi. Bandung : Fakultas Ekonomi Universitas Padjajaran.

Indra Bastian. (2006). Akuntansi Sektor Publik. Suatu Pengantar Jakarta : Erlangga

Jeria Handayani. (2007). "Penerapan Sistem Akuntansi Keuangan Daerah (SAKD) Dalam Mewujudkan Transparansi dan Akuntabilitas Laporan Keuangan Pada Pemerintah Kabupaten / Kota Di Provinsi Jawa Tengah". Skripsi. Bandung : Fakultas Ekonomi Universitas Padjajaran.

Jogiyanto. (2007). Metodologi Penelitian Bisnis Salah Kaprah dan Pengalamanpengalaman. Yogyakarta : BPFE.

Mardiasmo. (2004). Akuntansi Sektor Publik. Yogyakarta : Andi.

-...... (2004). Otonomi \& Manajemen Keuangan Daerah. Yogyakarta : Andi. . (2006). "Perwujudan Transparansi dan Akuntabilitas Publik Melalui Akuntansi Sektor Publik : Suatu Sarana Good Governance". Jurnal Akuntansi Pemerintahan. Vol. 2 No. 1 p. 1-17

Mulyadi. (2001). Sistem Akuntansi. Jakarta : Salemba Empat.

Nunuy Nur Afiah. (2009). Akuntansi Pemerintahan : Implementasi Akuntansi Keuangan Pemerintah Daerah. Jakarta : Kencana Prenada Media Group.

Peraturan Menteri Dalam Negeri No. 59 Tahun 2007 tentang Perubahan atas Peraturan Menteri Dalam Negeri No. 13 Tahun 2006 tentang Pedoman Pengelolaan Keuangan Daerah.

Peraturan Pemerintah No. 24 Tahun 2005 tentang Standar Akuntansi Pemerintahan.

Renovator S. (2004). Penerapan Sistem Akuntansi Keuangan Daerah (SAKD) Dalam Mewujudkan Transparansi dan Akuntabilitas Laporan Keuangan Pada Pemerintah Kabupaten Ciamis. Skripsi. Bandung : Fakultas Ekonomi Universitas Padjajaran.

Robert M. Kaplan \& Dennis P. Saccuzzo. (1993). "Psycological Testing Principles, Application, and Issue": Brooks / Cole Publishing Company Pacific Grove. California p: 126

Siregar, Baldric. (2001). Akuntansi Pemerintahan Dengan Sistem Dana. Yogyakarta : STIE YKPN

Sudjana. (2000). Statistika Untuk Ekonomi dan Niaga I. Bandung : Tarsito.

-... (1997). Statistika Untuk Ekonomi dan Niaga II. Bandung : Tarsito.

Jurnal Akuntansi Riset, Prodi Akuntansi UPI, Vol. 2, No. 1 
Sugiyono. (1999). Metode Penelitian Bisnis. Bandung : Alfabeta. -. (2009). Metode Penelitian Kuantitatif, Kualitatif dan R\&D. Bandung : Alfabeta. Suharyadi dan Purwanto. (2004). Statistika untuk Ekonomi dan Keuangan Modern, Jakarta : Salemba Empat.

Supramono dan Intiyas Utami. (2004). Desain Proposal Penelitian. Yogyakarta: Andi. 